\title{
The insignificant impact of the historical Jesus
}

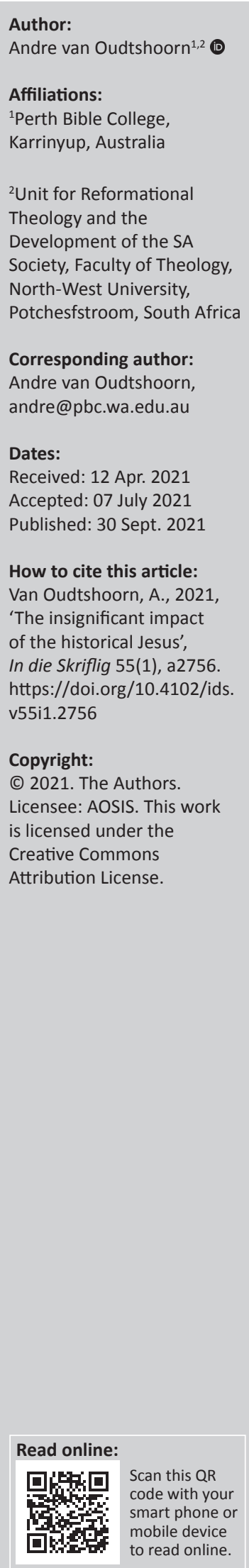

There is a natural tendency in the church to idealise the historical Jesus. This may lead to believers turning Jesus into an ideal moral or religious exemplar or lead to a prosperity gospel by predominantly focusing on the miraculous power and accomplishments of the earthly Jesus. This depiction of Jesus is in sharp contrast to the rejected and crucified Lord. This article follows a systematic theological methodology by challenging the theological framework which leads to the idealised perception of Jesus as a super-hero. The article does so, by reconsidering the interpretive framework employed to understand the inter-relationship between the person and actions of the historical Jesus, and the kingdom of God breaking through. I argue that the eschatological hermeneutical approach to salvation history best accommodate the tension between 'consistent' and 'realised eschatology', and help the church overcome the temptation to turn Jesus into a universal spiritual symbol or moral exemplar. The eschatological hermeneutical approadch to salvation history often focuses on the death and resurrection of Jesus, but I contend, should be expanded to include the life and ministry of Jesus. In this article it is argued that Jesus came to share in our human weakness and fallibility. Jesus fully experienced the 'not yet' of the Kingdom, by identifying and sharing in our lack of success. The unique character of Jesus as 'God who became human', sets him radically apart from all other humans and nullifies any attempt to idealise him. The resurrected and glorified Jesus whom the church worships, is and remains the crucified and rejected Messiah.

Contribution: The implications of the research will radicalise the believers' understanding of the significance of the incarnation. It challenges some of the assumptions regarding Jesus' power to help believers be successful in life. The article also holds pastoral implications for all those who experience the pain of failure, rejection and insignificance.

Keywords: Christology; kingdom; humanity of Jesus; anthropology; history.

\section{Introduction}

For most Christians, the impact of the historical Jesus cannot be overstated. He is admired for his kindness, his mighty miracles, his concern for the poor and the outcast, his moral teaching, his upliftment of woman and his sacrificial lifestyle. Even non-Christians often express admiration for Jesus of Nazareth. The focus on Jesus as an exemplary good man could, however, be theologically counterproductive. The legendary super-hero Jesus is far removed from the 'failed Messiah' we encounter in the Gospels. Losing sight of Jesus the human 'failure', who ultimately ends up on a cross, seemingly without inaugurating the kingdom of God, is to lose sight of the essential core of the gospel, and will have critical implications for our understanding of Christ, and humanity, salvation, spirituality and ethics.

The thesis of this article is that the church is called to acknowledge, identify with, and celebrate the insignificant historical impact of Jesus of Nazareth, instead of focusing on the hero-like features often ascribed to him. Most scholars recognise that Jesus did not meet the Messianic expectations of the Jews of his time. In this article, I wish to extend this lack of understanding to the church of today, where Jesus is often depicted as a superman, rather than God's ideal human who would willingly become a failure in the service of God's love. I support this thesis by setting Jesus and the kingdom of God within setting salvation history within a broader eschatological framework that could more fully accommodate the incarnation of Jesus, his ministry in inaugurating the kingdom of God, and his failed Messiahship. To achieve this, I will firstly provide a brief overview of different theological approaches to the inter-relationship between eschatology, the kingdom of God and the ministry of Jesus, which have been advanced from the 19th century onwards. The eschatological approach to salvation history, as developed by Oscar Cullmann, I will argue, successfully provides a hermeneutical framework that is broad enough to accommodate both consistent and realised eschatological perspectives on the coming of the kingdom. I do, however, argue that this framework has not been sufficiently utilised to accommodate the multiple modes, 
in which the kingdom of God was realised in and through the earthly ministry of Jesus. Without a more nuanced understanding of the various ways in which Jesus introduced the kingdom to earth, one may easily make too little or too much of the humanity of Jesus.

After broadening the eschatological salvation history to include the life, person and ministry of Jesus, I develop three critical theological arguments to illustrate the need to embrace a vision of Jesus which fully recognises his failures' and historical insignificance, especially when measured against humanity's urge to succeed. This focus on success has led believers to project their view of success onto Jesus, instead of recognising God's call for Jesus to 'become nothing' (Phlp 2:7) for the sake of broken humanity. Jesus, I will argue, became fully human, completely identifying with frail, fallible and sinful humanity. I will show the theological importance of this perspective on Jesus, and its implications for our understanding of ourselves, humanity in general, and the salvation wrought by him. Secondly, I argue that the historical Jesus can only be understood and interpreted in the light of his resurrection from the dead, which circumvents any attempt to evaluate him like any other human. The person of Jesus does not fit standard historiographical categories. As God who became human, He transcends every effort to identify with him. As God who became flesh, he challenges every effort to idealise him. Thirdly, I point out that the resurrection of Jesus did not displace the crucified and rejected Saviour as the focus of the church's worship. The resurrection resulted in the glorification of the rejected and despised Servant of the Lord. Only after thoroughly embracing the insignificant impact of the historical Jesus, shall we be able to identify and consider the lasting significance of Jesus of Nazareth, the resurrected Saviour of the world.

Any historical account of Jesus necessarily has to deal with the theological impact of his person on his disciples, and those who have later come to believe in him through their proclamation.

The church has always confessed that Jesus not only represented God in his commitment to humanity, but also humanity in its rejection of God. Without Jesus' association with broken humanity, much of what is said in the New Testament about the cross, as a symbol of the reconciliation between God and sinful humanity, remains incomprehensible. This raises the question: how does Jesus' apparent failure, culminating in his humiliating death on the cross, fit in with his proclamation of the coming of the kingdom of God? How is God's new rule on earth linked to the ordinary human Jesus of Nazareth?

\section{The kingdom as a spiritual reality (Schleiermacher and Bultmann)}

Jesus' proclamation about the coming of the kingdom of God stands at the heart of his ministry.
There has been much theological debate about the meaning and significance of Jesus' message about the kingdom. Schleiermacher's theology expounds on personal faith in God, rather than focusing directly on God (Allen 2012:152). Schleiermacher depicted Christ as the 'reformer of human knowledge about God' (Gerrish 1993:176). This 'Godconsciousness' reveals itself 'in the form of the feeling of absolute dependence' (Schleiermacher 2016:244). Jesus, according to him, established the kingdom of God by awakening a consciousness of God in humans, which 'establishes the dominance of spirit over the flesh' (Mariña 2005:165). For Schleiermacher, the spiritual world was more important than the physical world. His theology had no place for terms like $\sigma \omega \mu \alpha$ [body], $\sigma \alpha \rho \xi$ [flesh], $\theta \alpha v \alpha \tau o \varsigma$ [death], $\zeta \omega \eta$ [life], and $\alpha \dot{\alpha} \alpha \sigma \tau \alpha \sigma ı \varsigma$ [resurrection] (König 1969:20). Jesus' kingly power, as Schleiermacher saw it, was not concerned about the disposal and arrangement of the things of this world' (Schleiermacher 2016:476). From this, Schleiermacher concluded that 'nothing remains as the immediate sphere of his kingship but the inner life of men individually and in their relation to each other'. Schleiermacher (2016:425) linked the coming of the kingdom to the establishment of the church, by which Christ 'assumes us into this fellowship of His activity and His life'.

Schleiermacher (2016:449) also linked Jesus' miracles and moral message to his prophetic office. He advocated that the church's attention should be directed away from the specific physical miracles that Jesus performed, to the 'general spiritual miracle, which begins with the person of the Redeemer and is completed with the completion of his Kingdom'. Schleiermacher did not wish to set Jesus up as an external ideal of human perfection, that believers should directly emulate. Believers, according to him, may call Christ '... our satisfying representative' (Schleiermacher 2016:461). Through his redemptive activity, Christ perfected humanity. Christ attained an 'ideal dignity' and 'so represents, in his redemptive activity, the perfecting of human nature, that in virtue of our becoming one with him God sees and regards the totality of believers only in Him' (Schleiermacher 2016:461). The kingdom of Christ, he (Schleiermacher 2016:464) argues, 'extends only over those who have already been assumed into vital fellowship with him'. For Schleiermacher, with his emphasis on the faith of the believing community, the historical Jesus functions primarily as a theological catalyst for faith, which in turn, leads us to experience God more fully.

Rudolph Bultmann first made a name for himself in the search for the historical Jesus through his contribution to the development of Form Criticism. This historiographical methodology strove to go beyond the Gospels as the only historical sources for reconstructing the life of Jesus.

Form Criticism endeavoured to isolate and examine individual sayings and events about Jesus, to see if they display a similar form or pattern. These forms, according to Bultmann, are echoes of what Jesus did and said, and were later taken up to be used and manipulated by the early church and the gospel 
writers, to make theological points about him (Dunn \& McKnight 2005:88). Bultmann, however, ultimately rejected any endeavour to construct a 'merely reminiscent historical account' of Jesus. By this, he meant a historical account that has been stripped of the theological message surrounding the person of Christ. Dunn and McKnight (2005) put it as follows:

Interest in the historical Jesus was taken by Bultmann to be an illegitimate clinging to this-worldly props for faith, a desire for an objective verification of faith. The real Christ event, however, is the church's proclamation. (p. 215)

The danger of by-passing the historical life of Jesus, a danger to which Bultmann willingly succumbed, is that the person of Jesus may easily be turned into a mere theological symbol, designating God's spiritual act of salvation towards humankind. The life of Jesus is thereby reduced to a redundant prelude, to the symbolic event of the cross, which serves as a mythical expression of God's love for humanity. Bultmann thereby mirrors Schleiermacher's approach, which subjected Christology to anthropological concerns. For both Schleiermacher and Bultmann, the life, death and resurrection of Jesus ultimately become symbolic pathways, that lead individual believers to a personal spiritual encounter with God, and in this way, to the realisation of the kingdom of God within them. Ernst Käsemann, reacting to the German church's endorsement of the Nazi ideology, pointed out, however, that the church can only prevent Jesus from being co-opted into serving different political, ideological, or theological agendas, if it remains bound to proclaiming the historical Jesus of Nazareth. All theological reflection on the person and work of Christ must always return to the Jesus who lived and died a Jew at a particular time and place. It is only the Jesus of history, who can lay claim to the historical transformation of the world (Käsemann 2012:15-47).

\section{The kingdom as the society of loving people transforming the world (Von Harnack and Rausenbusch)}

The so-called 'liberal theologians' of the late 19th and early 20th centuries, such as Rausenbusch and Von Harnack, shifted their focus away from Schleiermacher's emphasis on a spiritual kingdom that is indifferent to, and an escape from, the broken reality of this world. The German American theologian Rausenbusch, believed that the coming of God's kingdom on earth was at the centre of all that Jesus did and taught. The purpose of the kingdom which Jesus had inaugurated, was to create a new kind of community, that could transform the world 'through the power of God's Kingdom-bringing Spirit' (Dorrien 2003:89). Von Harnack, in his book What is Christianity?, defines the kingdom as 'the pure prophetic religion taught by Jesus; the Fatherhood of God, the "brotherhood of man," the infinite value of the individual soul, and the ethic of love' (Ladd 1993:55). The liberal theological depiction of the kingdom of God did not threaten any cataclysmic, apocalyptic end to fallen reality; they instead, portrayed it as a steady, moral foundation on which to build a better world, through acts of love and kindness. According to these theologians, the kingdom of God is not removed from the plight of this world but shows itself as a 'civilising' and transforming power, that gradually improves believers and society in general.

Ridderbos (1962), rather cuttingly, responded to Von Harnack's assertion, that each human soul has infinite value as a precious child of God, by saying:

It is emphatically maintained with good reason that Jesus' preaching is much rather dominated by the conviction that man has lost his value and that, notwithstanding, God is willing to accept him. (p. 21)

\section{The kingdom belongs to the future}

The easy way in which the liberal theologians intertwined the coming of the kingdom of God with the improvement of secular society, was severely challenged in a short (67 pages!) booklet by Johannes Weiss, entitled Die Predigt Jesu von Reiches Gottes, which was published in 1892 (Weiss 2014:21). In his book, Weiss dismissed any notion that Jesus' references to the coming of the 'Kingdom of God', expressed the breakthrough of a spiritual reality that would evolve and expand over time. '... Von einer Stiftung und innerweltliche Entwicklung des Reiches kann keine Rede sein' [It is impossible to think of the kingdom being institutionally founded and evolving from intrinsic forces in the world] (Weiss 2014:21). According to Weiss, Jesus expected a catastrophic and cataclysmic future intervention by God. Jesus could do nothing to inaugurate the kingdom of God. He could only proclaim it and await it as some future event. Weiss' (2014:22) view that Jesus 'consistently expected the Kingdom to come by way of divine intervention', was taken up and further developed by Albert Schweitzer, to whom we return later in the article.

\section{The kingdom has already come (Dodd)}

C.H. Dodd, in reaction to Weiss and Schweitzer, championed the idea that Jesus believed and proclaimed that the kingdom had finally arrived in and through his ministry. While Dodd admitted that there are some saying of Jesus which could point to a future realisation of the kingdom, such as these in Matthew (3:2; 16:28; 26:29), Mark (13:10, 32) and Luke (9:27), he nevertheless argued that these sayings seem confusing and unsure, while 'the sayings which declare the kingdom of God to have come, are explicit and unequivocal' (Dodd 1978:40).

Dodd eliminated any sayings of Jesus which point to an apocalyptic breakthrough of the kingdom in the future, by either describing them as secondary compositions, or by relegating them to a symbolic transcendent reality, that has nothing to do with this world and its history (Dodd 1978:41). According to Dodd (1936:82): 'All these are eschatological in character: they are ultimates and are proper not to this empirical realm of time and space, but to the absolute order'. Jesus spoke about the kingdom as an experiential reality. In the apocalyptic writings, however, the meaning of the 
'kingdom of God' could only be expressed 'in terms of fantasy' (Dodd 1978:50). It is true to say that Dodd had much biblical material to support his arguments. The mighty miracles of Jesus and his exorcisms, all pointed to something dramatic happening in the coming of Christ to the world. Jesus himself connected his exorcisms to the present breakthrough of the kingdom of God in this world. 'But when I force out demons by the power of God's Spirit, it proves that God's kingdom has already come to you' (Mt 12:27-29). Daniel Harrington (1991:187) comments that this verse is perhaps the clearest reference to a 'present' or 'realised' eschatology in the Gospels.

\section{Contemporary views of Jesus and the kingdom}

To some extent, the battle between the consistent eschatology of Weiss and Schweitzer on the one hand, and the realised eschatology of Dodd on the other, regarding the coming of the kingdom in and through the earthly work and ministry of Jesus, is still being played out in modern scholarship. There are of course, some modern-day scholars who have drifted away from the eschatological tension surrounding Jesus and the coming of the kingdom, by depicting Him as a wise, itinerant teacher or mystic. In these cases, Jesus often ends up being presented in similar terms to the portrayal of Jesus by the liberal theologians. Jesus is shown as a teacher of timeless and general ethical and religious truths. Crossan, for instance, argues that Jesus set out to realise a 'brokerless kingdom', which challenged the socio-cultural system of the day, by proclaiming God's unconditional care for social 'nobodies'. According to Crossan (2010:421-422), Jesus was thereby promoting radical social equality, in contrast to the patronoriented social systems of the time. As Wright (1997:58) correctly points out, any depiction of Jesus as the bringer of such timeless, general truths, can only do so at the cost of dispersing with Jesus, the Jew.

Wright (1992:333) sides with Dodd's realised eschatology. He argues that Jesus' apocalyptic pronouncements are not to be taken as referring literally to God's final judgement at the end of time. The apocalyptic imagery is instead to be understood as symbolic representations of historical realities. According to him, there is 'virtually no evidence that the Jews expected the end of the space-time universe'. He argues that Jeremiah and the other prophets, utilised 'cosmic imagery' metaphorically, 'to bring out the full theological significance of cataclysmic socio-political events'. In his book, Jesus and the victory of God (1992), Wright sets out to strip Jesus' symbolic language and imagery of its transcendent, other-worldly, apocalyptic dimension:

Apocalyptic language, including language derived from Daniel 7 , would quite readily be understood in the first century as a retelling of Israel's national story, climaxing in the judgment of Israel's true enemies and the vindication of Israel's true representative. This means that warnings which utilize such language are not to be syphoned off as dealing only with some far-off future 'final judgment' in the sense of the space-time universe. Warnings of this sort are, on the contrary, exactly what we might expect on the lips of a prophet such as we have seen Jesus to be. (p. 325)

Wright (1997:172) argues that Jesus' message was filled with an immediacy and urgency which spoke to the people of the time. 'He was issuing a public warning, like a man with a red flag heading off an imminent railway disaster'. If Wright's view is accepted, then Jesus' ministry would have proven to be particularly disappointing to those who looked to him, and even proclaimed him as the Messiah. Marcus Borg is of the same view as Wright, although he accepts a futuristic eschatological dimension in a few of Jesus' pronouncements. He nevertheless classifies these as being on the margins of Jesus' real socio-political message (Borg 1998:221-231).

There is no doubt that some of Jesus' listeners may have interpreted his message politically. Still, it is also true that many of Jesus' pronouncements, such as the final separation of the sheep and the goats, reach beyond the socio-political context of the day, to set the whole world in a genuine apocalyptic fashion before the God who, as he announced, will finally destroy evil in all its forms forever. Thus, any understanding of the historical Jesus, will have to contend with the expectation of the immediate realisation of the kingdom of God, in and through the historical Jesus, as well as the absence of that realisation in and through his life, culminating in the climax of the cross. The eschatological hermeneutical approach to salvation history, to my mind, best succeeds in holding onto this tension.

\section{The understanding of Jesus and the kingdom according to this approach to salvation history}

I will enlarge the the eschatological hermeneutical framework for salvation history to explain the different forms in which the kingdom of God was manifested in and through the life and ministry of Jesus. The eschatological approach to (theological) salvation history endeavours to bind some of the diverse ideas about Jesus and the coming of the kingdom together. Oscar Cullmann, in his book, Christ and time, argued that the Bible reflects a linear understanding of history, in contrast to a cyclical, repetitive view of time. This linear view of time encompasses past, present and future. The early church, Cullmann (1962:62) argued, did not think in terms of timeless categories. God's final redemptive act is, and remain, bound to the historical coming of Christ into the world (salvation history). Cullmann further points to the Jewish delineation of time into 'this age', representing the present evil reality and 'the coming age' that they expected with the Messiah's coming. The dividing line or 'mid-point' between the ages of Judaism thus lay in the future. In contrast to this futuristic expectation, Cullmann (1962) notes:

The chronologically new thing which Christ brought for the faith of Primitive Christianity consists in the fact that for the believing Christian the mid-point, since Easter, no longer lies in the future. (p. 81) 
According to the New Testament message, Cullmann asserts, the mid-point between the present and the coming age now lies behind believers. The 'event on the cross, together with the resurrection which followed', has finally inaugurated the expected Messianic new age. The cross signifies the end of the old age, and the resurrection signifies the beginning of the new. This, Cullmann (1962) explains clearly:

No other point of time in the entire process, either in the past or in the future, can have so central a significance as this one has for men who are convinced that Jesus Christ has risen in bodily form as the firstborn from the dead. (p. 85)

The death and resurrection of Christ, signifying the realisation of the new age, Cullmann argues, does not do away with the future outside of, and apart from Christ. 'The center has been reached, but the end is still to come' (Cullmann 1962 84). The culmination $(\pi \lambda \varepsilon \rho \omega \mu \alpha)$ of time, which was realised in and through Christ, does not annul the expectation of future salvation. Ridderbos (1962) comments:

\begin{abstract}
Also, from the standpoint of the 'fulfilment in Christ' the kingdom is conceived as being future, and the state of the Christian as that of an heir of future goods. Therefore, the category of time is maintained as subject and subservient to the divine plan of salvation. It is not the victory over time but over that which opposes the consummation of the divine work in time which is the fruit of the pleroma which started with Christ. (p. 77)
\end{abstract}

The eschatological approach to salvation history accommodates a three-fold perspective on the kingdom of God. The kingdom has come to earth in and with the coming of Christ - it has thus become an already present reality. Secondly, the kingdom will be fully realised on earth with the return of Christ, it is, therefore, not yet a current reality on earth. Believers, thirdly, already experience the reality of the kingdom through their faith in Christ and the presence of the Holy Spirit in the church. At the same time, the Spirit groans with the church for the future return of Christ, and the final and complete realisation of the kingdom of God, which has not yet been realised. However, the eschatological tension between the 'already' and the 'not yet' has been unfairly limited to the church and the lifeworld of individual believers. This tension, I wish to urge, should be seen to apply equally to the person and work of the historical Jesus.

\section{The different modes of the kingdom's coming in and through Jesus}

Herman Ridderbos, using an eschatological hermeneutical approach to salvation history, argues that the pre-eminent characteristic of the kingdom of God is that it is theocentric. The coming of the kingdom, he states, is about God asserting himself as king in this world and revealing his 'royal power, majesty and might' (Ridderbos 1962:19). The kingdom of God primarily refers to the fulfilment of God's promises to and the affirmation of his rights over 'Israel, the heathen nations, the world, and even the whole creation' (Ridderbos 1962:23). The 'theocentric' character of the kingdom implies that it cannot be created or even promoted by human means.
The kingdom of God is never the result of human goodness, spirituality or moral endeavour. Instead, the kingdom is 'transcendent in its origin' and serves to reveal God's glory (Ridderbos 1962:24). The coming of the kingdom, asserts Ridderbos (1962:24), '[...] is nothing less than the great divine break-through, the 'rending of the heavens', (Is 64:1), 'the commencement of the operation of the divine dunamis (Mk 9:1)'. It is no wonder that Ridderbos (1962:25) depicts Jesus as 'actually and effectively' inaugurating the kingdom of God on earth. When Jesus proclaimed that the kingdom was 'at hand' (Mt 3:2; 4:17), or 'coming' (Lk 17:20; Mk 11:10), or 'should appear' (Lk 19:11), he was announcing the beginning of God's dynamic rule as King. The result of Ridderbos' 'realised eschatology' means that he has no place for the 'not yet' as a concurrent mode in which the kingdom is present in and through the ministry of Jesus. When discussing the kingdom of God as being 'Messianic' in character, Ridderbos argues that Jesus deliberately replaced

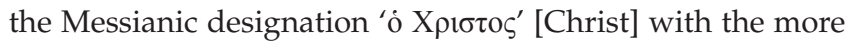
universal and transcendent eschatological title 'vios $\tau$ ov ’ $v \theta \rho \omega \varpi v^{\prime}$ [Son of Man].

\section{Miracles}

Jesus' miracles and exorcisms signified that something new and extraordinary was occurring in the world. And yet, the biblical witnesses also indicate that the way Jesus operated, raised serious doubts among those who witnessed his actions about the relationship between what Jesus was doing, and the coming kingdom of God. Jesus' actions did not meet the nationalistic expectations surrounding the coming Messiah. But doubts were also raised in the minds of witnesses, because of the nature of the person of Jesus himself. People in Jesus' hometown asked: 'Where did this man get this wisdom and these miraculous powers? Isn't this the carpenter's son? Isn't his mother's name Mary, and aren't his brothers James, Joseph, Simon and Judas?' (Mt 13: 54-55). Matthew concludes the pericope by observing in 13:58 that Jesus 'did not do many miracles there because of their lack of faith'. As a prerequisite for certain miracles to happen, Jesus' demand for faith stands in sharp contrast to the radical theocentric view of the kingdom that Ridderbos advocates. The kingdom's power could seemingly be resisted, and even nullified through people's lack of faith. The necessity of faith in realising the kingdom, does not mean that people's faith contributed to the coming of the kingdom, but that the kingdom of God came in a way that required a particular response from people. The people's faith was directed to Jesus as the worker of miracles, and not to the miraculous event itself. The recipient's faith thus did not make the miracle happening. Their distrust of Jesus, however, could prevent the miracle from taking place.

\section{Thesis one: Jesus' identification with human failure precludes any idealised view of him}

Jesus' incarnation means that he fully identified with broken, fallible and sinful human beings. He did not come among 
us as an 'all together', 'all successful', 'Superman Saviour'. He came to share in our weaknesses and failures. The Word became flesh. Flesh, in this context, Ridderbos (1962:49) says, 'signifies human existence in its weakness, perishability, dependence and the like'. It is by becoming 'flesh' that Jesus reveals his glory as the Son of God. Jesus' glory, according to John 1:14b, is not linked to his human perfection but to his identity as God's Son, who graciously came to earth to identify with weak and fallible people. The incarnation is the concrete expression of God's power in his humility and condescension. God, according to Barth (2004:130), through the incarnation, reveals that he can and does give himself up by accepting both the creaturely limitations and the suffering of humanity. Torrance (2008) eloquently states:

He comes as bone of our bone, and flesh of our flesh; he speaks with a human voice, is brought up in a human family, eats drinks, thirsts and is hungry, grows weary and is pained, rejoices and sheds tears, and is encompassed with our frailty and infirmity. Here in Jesus, the eternal God comes so near that he is a particular man among others, a particular historical individual, a frail human being, such a man in fact that people could easily pass him by as just another man, and easily fail to see anything else in him than ordinary humanity. (p. 185)

Hebrews 1-2 follow the same trajectory as the Johannine prologue. Jesus, the Son of God, so identified with his 'brothers and sisters' that he fully shared in their human temptations, fallibility, and I would add, lack of any significant earthly success. Schillebeeckx (2014:600 Volume 6, par. 638) notes:

Jesus' message is essentially intended to be a message about God and from God, a message which he maintained to the end, throughout the successes and failures of his life up to the historical fiasco of the cross, a seal on the authenticity of his life and message. (author's own italics) ${ }^{1}$

The humiliation of Jesus culminated in his death on the cross. Schreiner (2015:90), commenting on Hebrews 2:9 in which Jesus is said to have 'tasted, ( $\gamma \varepsilon v \sigma \eta \tau \alpha)$ death', argues that this phrase indicates that Jesus experienced all 'the frustration, futility, and despair of human existence'. This theme is further developed in the rest of the book. In Hebrews 5:7, for instance, we read:

During the days of Jesus' life on earth, he offered up prayers and petitions with fervent cries and tears to the one who could save him from death, and he was heard because of his reverent submission.

The NIV's (New International Version) translation 'during

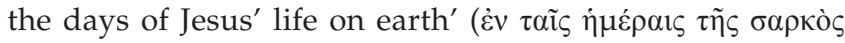

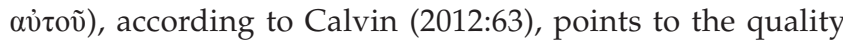
of Jesus' life on earth. Bruce (1990:126) sees this expression as referring to 'the condition of human weakness of which he partook during his earthly life $[\ldots]^{\prime}$. According to

1.Schillebeeckx, like Bultmann, radically separates the historical Jesus from the Jesus portrayed theologically in Scripture. He believed that the gospels' theologica presentation of Jesus does not reflect the reality of the historical Jesus (see Wrigh 2015:24). His depiction of the 'failures' of Jesus does not, therefore, lead to deepening of the theological interpretation of Jesus as the failed Messiah. While Schillebeeckx and I are seemingly using the same words to say something importan about Jesus of Nazareth, the theological frameworks in which our words operate, differ radically from each other.
Schreiner, this phrase denotes the 'frailty and weakness characterizing life on earth'. Jesus, he adds, was 'plagued with the sorrows and heartache of human existence'. The author of Hebrews, Schreiner observes, uses the plural 'days of his flesh' in this verse to indicate that Jesus had his full share of tears and sorrow throughout his life (Schreiner 2015:162). Jesus knew disappointment and failure. Jesus' inability to achieve 'earthly success', is demonstrated throughout his ministry. I shall only touch on a few instances to illustrate this point.

Jesus was a rabbi or teacher, but not necessarily the best teacher ever. People, including his disciples, often did not understand him. They often classified Jesus' stories as 'riddles' rather than 'explanations'. He taught with authority, but the religious leaders and the crowds frequently challenged and dismissed his teachings as obscure or irrelevant. 'Do you still not understand?' an exasperated Jesus asked of his disciples.

Many books on Christian discipleship endeavour to reflect Jesus' model of surrounding himself with a small group, who would live and travel with him and learn from him. Jesus' discipleship model, however, appears to have failed miserably. It did not turn out bold, brave, strong and committed followers - just the opposite. Of the 12, one betrayed him and committed suicide; another denied ever knowing him. The other 10 ran away and left him to his fate. Following his crucifixion, they all cowered together in fear for a while, before disbanding and returning to their former jobs.

Jesus had started his ministry proclaiming that the apocalyptic kingdom of God was near. He urgently called his generation to be ready for the cataclysmic appearance of God's MessiahKing, who would finally judge the nations and restore Israel. However, then, nothing happened. The world continued as before. John the Baptist, who had initially announced the coming of Jesus, the Messiah with certainty, ended up wondering if Jesus was indeed the expected Messiah.

Jesus suffered the same fate as many failed prophets before him. People did not repent after hearing his message, but instead turned against him and crucified him. As an undergraduate, I remember my dismay when I first encountered what I then considered Albert Schweitzer's 'blasphemous' depiction of the historical Jesus. In his famous Quest for the historical Jesus, Schweitzer concluded that Jesus had sent his disciples on their missionary journey, not to extend the kingdom of God, but to proclaim its nearness as a future cataclysmic and apocalyptic event from God. To Jesus' dismay, Schweitzer opined, 'the people's hardness of heart at length convinced Jesus that the establishment of the kingdom of God could not yet take place' (Schweitzer, The Quest, p. 238) Jesus, said Schweitzer, slowly realised that he must allow himself to be crucified to force the hand of God to inaugurate the kingdom. He (Schweitzer 1956) stirringly described Jesus as: 


\begin{abstract}
... laying hold of the wheel of the world to set it moving on that last revolution which is to bring all ordinary history to a close. It refuses to turn, and he throws himself upon it. Then it does turn, and crushes him. Instead of bringing in the eschatological conditions, He has destroyed them. The wheel rolls onward, and the mangled body of the once immeasurably great Man, who was strong enough to think of Himself as the spiritual ruler of mankind and to bend history to his purpose, is hanging on it still. That is his victory and his reign. (p. 239)
\end{abstract}

While not sharing Schweitzer's conclusions about the historical Jesus, I nevertheless contend that his vision of Jesus as the 'failed Messiah', is crucial to the church. Through the lens of the incarnation, we see that the ultimate success of Jesus' mission was intrinsically linked to his failure as a human to inaugurate the kingdom of God. Without this understanding of Jesus, we quickly end up with a hero instead of the humble and humiliated Son of God. As a hero, Jesus represents the ideal human with whom we can identify in our better moments or try to imitate as a way of escaping failures. This Jesus may inspire us to be better people, but he does not engage with us as we are as sinners. The incarnation was never about God holding Jesus up as the apex of human perfection. Jesus, then would be nothing more than a symbol signifying the human potential for self-improvement, or even self-divination. Behind this, I would suggest, lies the old temptation for humankind to want to become like God. The incarnation of Jesus, on the contrary, was always about God, in his Son, Jesus, so identifying with weak, fallible, unsuccessful, and sinful people that he became like them. By focusing on the achievements of the historical Jesus of Nazareth, we are saying too much about humanity and too little about God.

\section{Thesis two: Jesus' life without his resurrection would have amounted to nothing}

I argue that the historical Jesus of Nazareth would have just disappeared from history, if he had not been declared with power to be the Son of God through his resurrection from the dead (Rm 1:4). Schillebeeckx (2014) puts it as follows:

Purely historically his life's project was a failure. Hence his message and conduct, however essential, cannot be the final word, at any rate, if they are to be a ground of real hope. The gospel's response to this problem is the belief in Jesus' resurrection. (p. 602 Vol. 6, par. 642)

The resurrection of Jesus sets him apart from all other humans. The biblical authors portray Jesus through the lens of the resurrection. Jesus may be the main character in the gospel stories, but the reader is never transported to relive the story's events through him. The Gospels instead, transport their readers to see the story through the eyes of an omniscient narrator, who already knows that Jesus is the resurrected Son of God. I thus concur with James Dunn, that the Jesus we encounter in the Bible is 'Jesus remembered'. The church always recognised that he was more than just another historical figure: he was the Son of God, who was shown to be the Son of Man through his resurrection from the dead.
The resurrected Jesus does not neatly fit into history. We know from the incarnation that Jesus lived and died in a specific place and time, as an ordinary historical figure, the same as any other person. However, the resurrection of Jesus challenges our fundamental understanding of history as a set of events, that are analogous to other historical events, or a set of activities that can be shown to have been caused by other past actions and circumstances. The radical newness of the resurrection, which intersects the presence, not from the past, but the future, means that our understanding of history must change, to accommodate this non-analogous and nothistorically-caused eschatological event. The end of the Old Dispensation and the beginning of the New, were realised in and through the person of Jesus of Nazareth, the incarnate Son of God, coming into our time. Standard historiography has no categories within which to accommodate the radically new reality, inaugurated by the resurrection of Jesus, which brought history to its conclusion, without extinguishing the continuing unfolding of historical events.

The eschatological resurrection of the historical Jesus of Nazareth, attests that he was fundamentally different from everyone else. Schweitzer (1956), at the end of his Quest for the historical Jesus, concluded:

He will not be a Jesus Christ to whom the religion of the present can ascribe, according to its long-cherished custom, its thoughts and ideas, as it did with the Jesus of its own making. Nor will he be a figure which can be made by a popular historical treatment so sympathetic and universally intelligible to the multitude. The historical Jesus will be to our time a stranger and an enigma. (397)

Jesus, it must be said, has been, and will remain, a stranger and an enigma for all times. The divine character of Jesus as God's obedient Son, and the eschatological Son of Man, does not allow us to evaluate him using the same criteria as for other historical figures. The resurrection of the crucified Christ superimposes an alternative evaluation of the person and work of Christ onto the broken, rejected and failed Messiah, without replacing the significance of his rejection and crucifixion. There is no purely historical Jesus in the gospel, only the historically resurrected Jesus. The unique, incarnate Son of God alone could become the promised eschatological Son of Man; only the perfect eschatological Son of Man could exclude all other people from his eschatological death, for their sake. Only the eschatological historical Jesus lived entirely for God and others, in love. In the historically resurrected Jesus, all history has become eschatology and all eschatology Christology. Christology has become Soteriology and Soteriology, Theology.

Kim (2016:107-109) does not want to link Jesus' weakness to his voluntary identification with fallen humanity. Instead, he argues that weakness is a positive human trait that allows for 'mercy, solidarity and change of mind'. Weakness thus does not stand as a negative contrast to power.

Kim argues from 2 Corinthians 13:4a, that Jesus was crucified

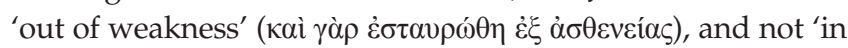
weakness' as the NIV translates the phrase. Jesus' weakness, he argues, is not something into which he willingly entered 
by laying aside his divine power to procure salvation for humanity. Jesus died because he did not have the power to prevent his crucifixion. Collins (2013:255-256), commenting on 2 Corinthians 13:4, affirms that Christ's weakness results from his human condition. In this pericope, he points out, the power of Christ is an alien power - it is by God's power that Christ lives. Christ's weakness, he argues, was the vehicle for God's power to work through him. Further, Jesus' plea in Hebrews 5:9 towards the one who could save him from death', means that he, like all other human beings, was by nature destined to die. In Hebrews 5:9, as in John 1, 'flesh, death, and darkness' cluster together. In life, Jesus was already tasting death. Jesus' life, because it was susceptible to death, was from the onset marked by suffering - what Augustine referred to as privatio boni [that which spoils the good].

Nevertheless, I would argue that Paul's point is not to elevate human weakness as valuable in and of itself. The weakness of Christ did not dignify human weakness. Humanity's weakness instead, is shown to have been overcome, and made subservient to God's power. Throughout 2 Corinthians, Paul sharply contrasts power and weakness (see 12:5-10, 13:3-14 and 13:9). Barnett (1997) comments:

The plural 'weaknesses' is used by Paul for his concrete 'sufferings' sustained through ministry (see 11:30; 12:5, 9, 10). The crucifixion of Christ was characterized by his utter physical helplessness. Yet, out of such weakness God wrought salvation ... In his powerlessness to save himself lay his hidden power to save others. A balancing use of $\dot{\varepsilon} \kappa$ appears in the following, 'out of the power of God'. (p. 603)

In this article, I strongly argue that we need to take the human fallibility of Jesus very seriously.

However, seeing Jesus as fully human does not dissolve the paradox that it is Jesus, the Son of God, who had become fully human. Jesus' ministry is open to being interpreted as a fully realised eschatology (Dodd), in which the power of the kingdom had been made manifest through his actions, as well as a consistent eschatology in which (Weiss and Schweitzer) the power of the kingdom belonged to the future. Jesus, the resurrected Son of Man, does not negate the historical insignificance of Jesus of Nazareth - the rejected and despised Servant of the Lord. Through the prism of his resurrection, Jesus' ultimate failure, dying as a criminal on a cross, revealed his glory as the eternal Son of God. The Jesus whom God raised from the dead, was and remains the incarnate, crucified Jesus of history. Any attempt to speak of the accomplishments of Jesus of Nazareth, apart from his divinity as the Son of God, who became 'nothing' for our sake, is to miss the real significance of his person and work. We may end up exchanging the foolishness of the cross for the glory of humanity.

\section{Thesis three: the gospel focuses on the resurrection of the rejected Messiah}

Even though already participating in the eschatological kingdom, the church, in and through the Spirit of the resurrected Jesus, is called to remain focused on and committed to the rejected, crucified Jesus.

In his study of the ethical implications of 1 Corinthians 15, Paul Brown argues that the Greco-Roman view of the after-life, strongly influenced the Corinthian believers. They viewed it as a shadowy place of semi-existence for ordinary people, and the place where public heroes would attain blessed immortality. Brown argues that Paul employed this ideological perhaps by depicting the resurrected Christ as such a hero to the Corinthians. Paul, according to him, insisted that the Corinthians should understand themselves as sharing in the status of Christ, their resurrected Saviour-hero, and therefore, to imitate the moral example of Christ. Paul thus also presented himself as such a heroic imitator of Jesus, willing to face danger and hardship in this life for the sake of others (Brown 2012:104-105). One has to wonder, however, if Paul would have deliberately employed the idea of people being or becoming 'heroes' in a context where he had to challenge the Corinthians about their pride, spiritual competitiveness, and selfish attitudes. Paul's inversion of the cultural norms throughout this letter, regarding what is 'important', 'wise', and 'successful', also seems to argue against Brown's thesis. Paul summarises his gospel as 'Christ crucified'. While the church worships Jesus as the resurrected Lord, the full implications of his resurrection are linked to his future coming. The church is called to identify with and emulate the crucified Christ, who suffered on behalf of the world. The power and status of the church, as co-regents with her risen Lord, are expressed in her willingness to identify with the shamed and broken, crucified Jesus.

The Spirit of Jesus, which God gave to the church, calls believers to find their identity in the rejected and annihilated historical Jesus. It is only through this identification with the 'broken Jesus', that the church embraces humility. Only through seeing her sinfulness revealed in God's judgement on the crucified Jesus, may the church identify with evildoers and sinners. It is only by embracing the crucified Jesus that the church remains marked by grace. It is only through the crucified Jesus that the church can give up her dignity and glory, in love for the sake of those who hate her and her Lord. Moltmann (2010) passionately states further:

By accepting the cross, the suffering and the death of Christ, by taking upon it the trials and struggles of obedience in the body and surrendering itself to the pain of love, it proclaims in the everyday world, the future of the resurrection, of life and the righteousness of God. (p. 163)

\section{Conclusion}

For a long time, under the influence of Schleiermacher and Bultmann, the kingdom of God was viewed as a purely spiritual reality in which people participate by faith, through an existential encounter with God. The so-called liberal theologians asserted that the kingdom might be realised on earth through the good and moral actions of people, who have been, or is being, transformed to become more like 
Christ. Many idealised portrayals of Jesus of Nazareth today reflect the same underlying thought pattern. Tension developed between theologians who believed that Jesus had inaugurated the kingdom on earth, and those who believed that Jesus expected the coming of the kingdom as a future event. I have shown that both dimensions of the kingdom were operating concurrently during Jesus' life and ministry. Jesus existed within the eschatological historical salvation tension, between the 'already' and the 'not yet'. Failure to do justice to this tension, inevitably resulted in the spiritualising of Jesus, turning him into a symbol of human potential and ultimate perfection.

There is no doubt that many fair-minded non-Christians would agree, that Jesus radically impacted people's view on the status, value and role of women; that he stood up for the poor and dispossessed; that he welcomed children to himself. They would acknowledge that Jesus gave the world new ethical insights by which to live. For many people, Jesus was a good man who is worthy of emulating. Jesus of Nazareth, the incarnate Son of God, I have shown, however, fell short compared to other worldly heroes. In life, Jesus was nothing more than an ordinary human who operated in the backwaters of Galilee, with a few miracles to his credit. Jesus identified with fallible, broken sinners, becoming who we are, even to the point of 'becoming sin'. His earthly 'ministry' ended in failure and despair. Only in this way could he represent us with our failures, faults and foibles.

An idealised view of Jesus of Nazareth, I have suggested, is the result of the intrinsic human need for an idealised view of ourselves as potentially perfect. The idealised historical Jesus becomes the apex of what it means to be genuinely human. However, this picture of Jesus turns Jesus into an 'ideal' to value and imitate; a 'motivational figure', rather than the incarnate Son of God. I have further shown the Jesus of Nazareth we encounter in Scripture, is the resurrected Son of God and not just an ordinary person. The resurrection affirmed that Jesus represented all that humanity could never be or attain: the human being who was perfect in God's sight. The perfection of Jesus as God's unique Son excludes sinful people from identifying with him, in any way. The exclusion of sinners from Jesus, the perfect Son of God, forms the ground of human salvation. Jesus died alone, in the place of those who had no right or possibility to be part of Him.

The church is called to continue to focus on and identify with the crucified Lord, as she awaits the coming of Jesus, the resurrected Lord. Only in this way, as a corecipient of grace, can she identify with the world for whom her Lord gave his life. Only in this way can the church represent Jesus, the broken, fallible Saviour. Only in this way, is there hope for ordinary people like us - people who often fail God, ourselves and others. Jesus identified with those whom the world counts for nothing. Only as we bow before the broken and rejected Saviour, who was humiliated and shamed on the cross, do we see ourselves for who we truly are: those securely held by the pierced hands of Jesus of Nazareth, the crucified Messiah, Son of God, Lord of the church and Saviour of the world.

\section{Acknowledgements Competing interests}

The author has declared that no competing interest exist.

\section{Author's contributions}

I am the sole author of this work.

\section{Ethical considerations}

This article followed all ethical standards for research without direct contact with human or animal subjects.

\section{Funding information}

This research received no specific grant from any funding agency in the public, commercial, or not-for-profit sectors.

\section{Data availability}

Data sharing is not applicable to this article as no new data were created or analysed in this study.

\section{Disclaimer}

The views and opinions expressed in this article are those of the author and do not necessarily reflect the official policy or position of any affiliated agency of the author.

\section{References}

Allen, P.L., 2012, Theological method: A guide for the perplexed, Bloomsbury, London. Barnett, P., 1997, The second epistle to the Corinthians, Eerdmans, Grand Rapids, MI.

Barth, K., 2004, Church dogmatics the doctrine of reconciliation, volume 4, part 1: The subject-matter and problems of the doctrine of reconciliation, Continuum International, London.

Borg, M., 1998, Conflict, holiness, and politics in the teachings of Jesus, Clark, London.

Brown, P.J., 2012, Bodily resurrection and its significance for ethics: A study of 1 Corinthians 15, Trinity Evangelical Divinity School, Trinity.

Bruce, F.F., 1990, The epistle to the Hebrews, Eerdmans, Grand Rapids, MI.

Bultmann, R., 2012, Jesus Christ and mythology, SCM, London.

Calvin, J., 2012, John Calvin's commentaries on St. Paul's epistle to the Hebrews: eBook edition, Jazzybee Verlag.

Collins, R.F., 2013, Second Corinthians, Baker Academic, Grand Rapids, MI.

Crossan, J.D., 2010, The historical Jesus: The life of a Mediterranean Jewish peasant, HarperCollins, San Francisco, CA.

Cullmann, O., 1962, Christ and time: The primitive Christian conception of time and history, SCM, London.

Dodd, C.H., 1936, The present task in New Testament Studies, Cambridge University Press, Cambridge.

Dodd, C.H., 1978, The parables of the kingdom, Collins, Toronto.

Dorrien, G.J., 2003, The making of American liberal theology, Westminster John Knox, Louisville, KY.

Dunn, J.D.G. \& McKnight, S., 2005, The historical Jesus in recent research, Eisenbrauns, Winona Lake, IN.

Gerrish, B.A., 1993, Continuing the reformation: Essays on modern religious thought, University of Chicago Press, Chicago, IL.

Harrington, D.J., 1991, The Gospel of Matthew, Liturgical Press, Collegeville, PA.

Käsemann, E., 2012, Essays on New Testament themes, SCM, London.

Kim, Y.S., 2016, Messiah in weakness: A portrait of Jesus from the perspective of the dispossessed, Wipf \& Stock, Eugene, OR. 
König, A., 1969, Jesus Christus die Eschatos: Die fundering en struktur van die eskatologie as teleologiese christologie [van] Adrio König, N.G. Kerk-Boekhandel, Pretoria.

Ladd, G.E., 1993, A theology of the New Testament, Eerdmans, Grand Rapids, MI.

Mariña, J., 2005, The Cambridge companion to Friedrich Schleiermacher, Cambridge University Press, Cambridge.

Moltmann, J., 2010, Theology of hope, SCM, London.

Ridderbos, H.N., 1962, Coming of the kingdom, P \& R Publishing, Phillipsburg, NJ.

Schillebeeckx, E., 2014, The collected works of Edward Schillebeeckx Volume 7: Christ: The Christian experience in the modern world, Bloomsbury, London.

Schleiermacher, F., 2016, The Christian faith, Bloomsbury, London.
Schreiner, T.R., 2015, Commentary on Hebrews, B\&H Publishing, Nashville, TN.

Schweitzer, A., 1956. The quest of the historical Jesus, 3rd edn., Adam \& Charles Black, London.

Torrance, T.F., 2008, Incarnation: The Person and life of Christ, IVP Academic, Downers Grove, IL.

Weiss, J., 2014, Die Predigt Jesu Vom Reiche Gottes (1892), Literary Licensing LLC, Whitefish, MT.

Wright, N.T., 1992, The New Testament and the people of God, Fortress, Minneapolis, MN.

Wright, N.T., 1997, Jesus and the victory of God, Fortress, Minneapolis, MN. 